\title{
AN ANALYSIS OF HUMAN CAPITAL DEVELOPMENT AND PRODUCTIVITY GROWTH- CASE STUDY, NIGERIA
}

\section{Adejumo Oluwabunmi Opeyemi, Adejumo Akintoye Victor}

(1) Institute for Entrepreneurship and Development Studies, Obafemi Awolowo University, Ile-Ife, Osun State, Nigeria,

(2) Department of Economics, Obafemi Awolowo University, Ile-Ife, Osun State, Nigeria

Adejumo Oluwabunmi Opeyemi Institute for Entrepreneurship and Development Studies, Obafemi Awolowo University, Ile-Ife, Osun State, Nigeria jumobum@gmail.com

Article info

Paper category: Review paper

Received: 23.5.2017 Accepted: 20.9.2017. JEL classification: $\mathrm{O}_{4}, \mathrm{O}_{15}$ 


\begin{abstract}
In order to address the direction of causality between human capital and productivity growth in Nigeria, the study first investigated the pattern of productivity growth in Nigeria between 1970 and 2010. Following the endogenous growth model, which argued that technical progress, through an effective labor force, could lead to long-run growth which can be determined from within an economy; but it actually depends on the efficiency with which resources available to such an economy are utilized. This is against the exogenous growth model which emphasized that long-run growth can be attained by some unexplained technological progress, which is exogenous to any economy. Based on this controversy in literature, this study empirically determined the productivity growth in Nigeria, as well as the causal relation between human capital development and productivity growth in Nigeria using the Engle-Granger causality test. The results revealed that productivity growth has been very low and unstable in Nigeria as it oscillated between $-1.5 \%$ and $0.6 \%$. In addition, the nexus between human capital and productivity growth was examined. The findings revealed that while productivity growth caused human capital development, human capital development did not cause productivity growth.
\end{abstract}

\title{
Keywords:
}

Human Capital; Growth; Productivity; Causality; Education 


\section{INTRODUCTION}

The growth literature is definitive on the centrality of the productivity improvement to the fostering of growth and development, (Meier, 1970). Aside the stock of physical capital, human capital, knowledge and technical know-how, has been identified as one of the components that can contribute positively to productivity growth, (Romer, 1996). Human capital which has been identified as the aggregate economic view of human beings acting within economies, encompasses traits such as knowledge, talents, skills, abilities, experience, health, intelligence, training, judgment, and wisdom (Mincer 1993; Becker, 1994). Therefore, given these attributes, human capital can be advanced through improvements in the productivity growths. This could be strengthened through the development and adoption of new methods and especially indigenous methods or approaches to productive and economic activities. Although, several theories have connected human capital development to issues such as health, education, economic development, productivity growth, and innovation; however, empirics have also stressed the need for education and quality investment in human capital for productivity enhancement (Mohammad and Jalil, 2011). Thus, this explains the continuous agitations and justification for government subsidies for health, education and job skills training.

Solow (1956) was the first to formalize the study of productivity growth within the context of an aggregate production function model. In an empirical analysis applied to the U.S. economy for the period 1909-1949, he discovered that gross output per man-hour doubled over the study period, within which $87.5 \%$ increase was attributable to technical change. Thus making a case for an improvement in technological patterns influencing human capital development; that an improvement in technical know-how, leads to increases in average output. Similarly, Soon and Soon (1997) examined the sensitivity of productivity growth to changes in the assumed service life of fixed service in Singapore for the period $1975^{-1995}$. It was discovered that productivity growth, was relatively weak in the late 1970 s and the early 1980 . However, this weak trend was observed to have rebounded due to improvements in the educational attainment of the labor force as well as the impact of skill upgrading.

On a different note, it has been revealed that it is not in all cases the presence of human capital can fast track productivity growth; this may be due to external shocks from funding, new trends, processes and approaches in production and service delivery. Hence there may be the need to develop human capacity to respond to the dynamics of our world. Estevao and Severo (2010) investigated how changes in industries' funding costs affect productivity growth. It was revealed that increases in the counterpart funding had a statistically significant and economically meaningful negative impact on productivity growth. This finding could not be explained by either increasing returns to scale or factor hoarding. This is because the results generated were not sensitive to controlling for industry size despite that the calculations ac- 
counted for changes in factor utilization. But based on a stylized theoretical model, the estimates generated suggested that financial shocks distort the re-allocation of factors, such as human resources, materials or machines, across firms even within an industry, thereby, reducing productivity growth, especially in the short-run. Furthermore, the decline in productivity growth could be largely attributed to negative impact of funding costs on output. This implied that when new processes are introduced into production systems, it is required that college training, on-the-job training respond to these changes as human capital are a major factor input towards productivity growth. Thus, the impact of funding geared towards human capital development should be examined if there will be a positive response to any shock that occur due to changes in current trends.

Several studies have examined the nexus between different variables and productivity growth in Nigeria, (Chete and Adenikinju, 2002; Olaoye, 1985; Adesina, 2011); but the relation between human capital development and productivity growth is still open in Nigeria. For an economy to develop its productive capacity there is the need to strengthen the human capital content. Prior, if the human capital base of an economy is well developed, it is expected to have significant implication for overall growth of such country. In the light of the foregoing, the question that comes to mind is what is the human capital base of Nigeria like? Besides, if the challenge of world dynamics is constant, to what extent has the government of Nigeria responded to this challenge, especially in terms of funding human development? In addition, in the light of global technological advancement, to what extent has productivity growth fared in Nigeria? And finally it may be important to know if any causal relation exist between the human capital base and productivity patterns in Nigeria

For macro and domestic factors to thrive sustainably, the variation in the level of education embodied in the labor force is required for productivity growth. As a matter of import, this technological know-how and performance is one of the primary reasons for the observed differences in productivity among countries, (Solow, 1956). For Sub-Saharan countries particularly, it was observed that the relevant bottlenecks preventing the development and adoption of new technology is the lack of human capital necessary to implement the new technology in a productive fashion, (Miller and Upadhyay, 2000); hence this study.

The study took a two-fold turn, because, if the causal relation between human capital and productivity growth is to be established, then the existing productivity growth trend must be established. Following this, the direction of causality between human capital is examined. In the light of this, the study is further divided as follows: section two examines some previous empirical studies on the relationship between human capital and productivity growth; section three examines the extent of government response to funding education in Nigeria, which is a germane factor for human capital development; sequel to this, section four and five gives the hypothesis and methodology of the study. While section six and seven presents the results of esti- 
mation, discussion of results and contribution to knowledge; and section eight concludes the study.

\section{LITERATURE REVIEW}

This section examines the various studies that have examined the nexus between human capital and productivity growth. Some studies revealed that the presence of newer technologies have facilitated effective labor output, while some have discovered that, scaling capabilities through learning, innovation and knowledge acquisition have improved human effort towards productivity growth.

Limskul (1988) compared productivity growth among the Newly Industrializing Economies (NIEs), where he discovered that productivity growth in the primary sector, with skills and technical know-how available, was quite low in Thailand compared to Japan; while productivity growth in the service sector was high in the Republic of China and the Republic of Korea. Besides, the growth of capital contributed more to the growth of GDP, which was quite similar to that in Japan. The efficiency of labor, which is advanced human skill, contributed more in the case of Republic of China and Republic of Korea. In a similar study, Tinakorn and Sussankarn (1994) also compared the results of the analysis with those in the other Asian countries. Multiple regression analysis was used to determine factors determining productivity growth. It was observed that if a country is to develop its labor force and improve its stock of knowledge, production for subsistence must be discouraged. In addition, capital accumulation which will enhance efficiency should be a ready complement to human development. This is because labor cannot work in isolation, besides after knowledge acquisition; there must be good forum to dissipate what has been learnt, thus promoting total growth.

Park (2010) in a study analyzed the changes in productivity growth in 12 Asian economies - the People's Republic of China; Hong Kong, China; India; Indonesia; the Republic of Korea; Malaysia; Pakistan; the Philippines; Singapore; Taipei, China; Thailand; and Vietnam - for the period 1970-2007. Special emphasis is placed on variables such as human capital, and research and development capital, in defining the productivity dynamics. The results showed the evidence of growing contribution of productivity in the post-2000 period. In the empirical model, estimate of productivity growth was augmented with human capital and R\&D. It was revealed that catchup effect by labor force, life expectancy effect, human capital, and R\&D were adopted as the baseline projection equations for TFP growth. In fact, within the Asian economies, the major source of productivity growth was found to be the catch-up effects by the labor force in the early 1980s, especially because the role of human capital in influencing TFP growth was seen to be gradually rising. Similarly, Idris (2007) analyzed the productivity growth in Malaysia during 1971-2004. Empirical result suggests that productivity growth of the Malaysian economy for the entire study period 
has not been encouraging due to negative contribution from technical efficiency. Although, it was discovered that the economy was able to cause shifts in their production frontier due to indigenous innovation; but, the economy needs an enhancement of their productivity-based catching up capability, specifically, the effective use of human capital in the labor market, increase in the number of skilled workers to operate a more sophisticated technology, and the adoption of new technology.

Danquah et al. (2011) examined productivity growth and its determinants in 67 countries (OECD and Non-OECD). Employing the non-parametric Data Envelopment Analysis (DEA) technique to compute the Malmquist productivity-based index for these countries, over the period 1960-2000, it was discovered that that the most robust productivity growth determinants are unobserved heterogeneity determinants common to OECD and non-OECD countries. For the OECD countries, a major factor that caused productivity growth was the efficiency with which labor force contributed; while in Non-OECD countries, the only additional variable that correlated with TFP growth is population density, thus re-affirming the role of human skill and labor force development in advancing productivity growth.

In another study, Ahmed and Bukhari (2007) showed that policies affect productivity through human endowments of employed labor force, providing better infrastructure and other facilitation to incorporate technology in the production process. Using the Pakistan economy from 1973 to 2006, human capital improvement accounts for a significant contribution in agriculture thereby, fostering the fostering the growth of productivity. While in Sub-Saharan Africa region, Akinlo (2006) explored the effect of macroeconomic factors on productivity growth in Nigeria, in 34. Sub-Saharan African Countries for the period 1980-2002. It was revealed that human capital; amongst other variables have significant positive effect productivity growth.

Therefore, in as much as human capital development has been seen as focal to changing the tide of productivity growth in some countries, such as the Asian tigers, it is relevant to examine where Nigeria is and where it need to improve on, if it is going to go beyond the least developed economies.

\section{EDUCATION FUNDING AND HUMAN CAPITAL DEVELOPMENT IN NIGERIA}

In most countries of the world, government as representatives of the society set economic goals which usually include economic growth, human capital development, equality in income distribution, low unemployment, high productivity growth, low inflation, high per capita income, favorable terms of trade and balance of payments. Usually, these goals may be incompatible with one another in terms of tradeoffs and struggle for resource allocations. But, they are usually seen as critical factors to ensuring development in any economy in the world. In order to attain these goals, 
there may be the need for a balanced budgetary allocation to address all the sub-sectors of the economy.

From the previous section, it has been discovered that if an economy is to develop its human capital base, there must be the support of capital resources to complement human capital development. These capital resources could include Federal funding through increased budgetary allocation to the educational sector, infrastructural development, enactment of policies, provision of subsidies, grants, scholarships, as well as an enabling environment that support learning. Amongst all these variables for human capital development via the educational sector, the major issue of concern is government effort, through policy development and funding patterns, geared towards improving educational system.

The Nigerian government has adopted several programmes and policies from 1970 to 2009 to address the issue of productivity growth. With particular emphasis on human capital development in education, the government in Nigeria in the mid-197os launched the Universal Primary Education (UPE) where education at the primary level was free; but due to certain inadequate needs assessment, in terms of increased turn out of school pupils, manpower and infrastructure, the programme gradually died a natural death. UPE, has since been replaced with the Universal Basic Education (UBE) programme, (Gusau, 2008). The government although has special arrangements for the UBE programme through budgetary allocations to education and private collaborations, it is observed that education funding has not gone beyond $14 \%$ of the total budget. From figure 1 , the funding of education in relation to the total budget allocation for education was 3.8\%, by 1990, the allocation for education had gone up to $7.2 \%$, while in the year 2000 , the funding of education was $12.5 \%$, and in recent times the allocation is about $11 \%$ of the total budget, (Budget report, 2014).

Figure 1.: Trend of Education Funding in Nigeria (1980-2005)

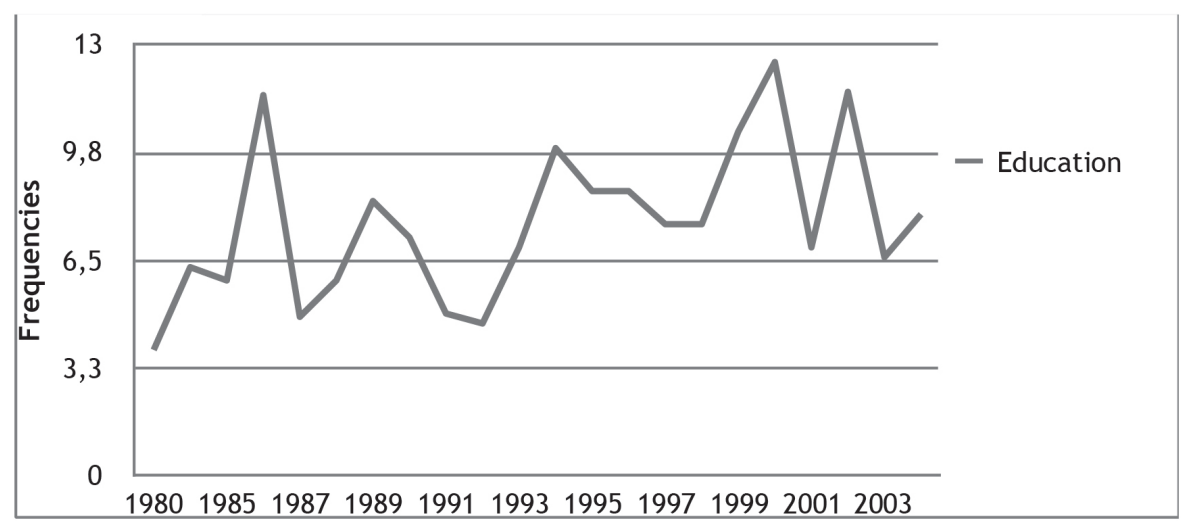

Source: Major Financial and social indicators, Central Bank of Nigeria (2005) 
In view of these policies, there is no doubt that from 1970 till the present time, the Nigerian economy has been experiencing relative economic growth as depicted by the growth rate of GDP, (World Development Indicators, 2013). In fact, taking over from South Africa, in 2014, statistics revealed that Nigeria has the largest economy, yet in terms of development ${ }^{1}$, Nigeria is still categorized amongst the least developed economies of the world, (Todaro and Smith, 2011; UNIDO, 2003). From Figure 2., a cursory look at the human development, in the light of secondary school enrollment, showed that from 1970 -till date, human capital has been growing in $\mathrm{Ni}$ geria. The puzzle then is, if human capital has been growing steadily through funding and enrollment rate, why has it not translated to development in Nigeria?

Figure 2.: Human Capital Development in Nigeria, 1970-2010

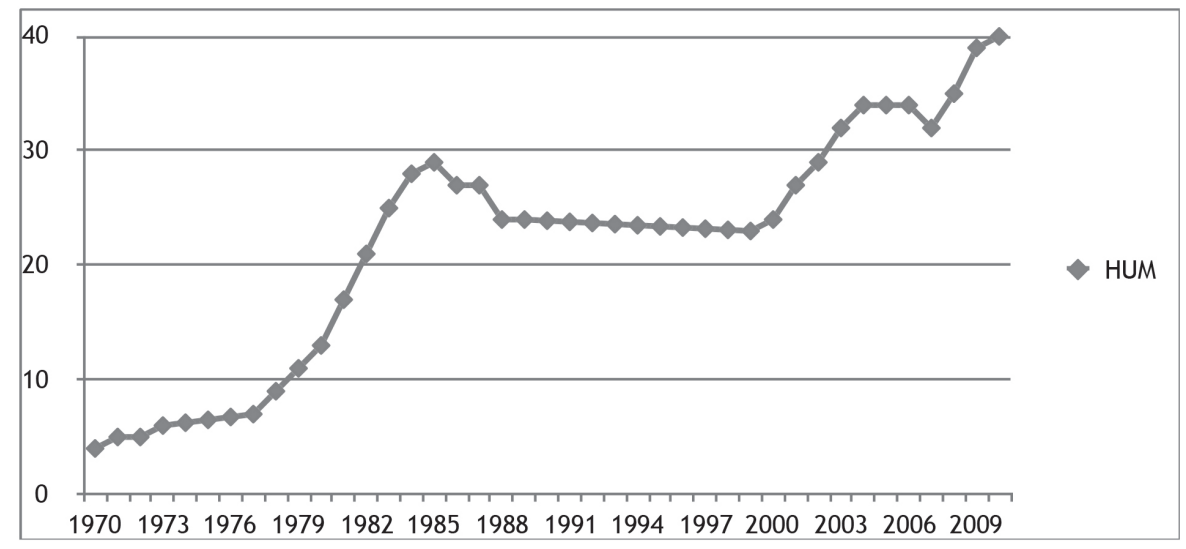

Source: World Development Indicators (2011)

Previous studies have noted some reasons for the deviations. For instance, Dauda (2010) noted that the ultimate goal of economic development which underscored the need to improve the well-being of people might just have been undermined; or unresponsive to global pace and requirements for development.

Over the years, recognizing the need to develop the stock of knowledge available to an individual successive Nigerian government had embarked on various programmes and projects which led to the establishment of educational institutions throughout the country. However, in the late 1970s and early 1980s, Federal government spending grew substantially resulting in fiscal crisis, inflation, and heavy borrowings. Subsequently, through the austerity measures adopted in 1982 and Structural Adjustment Programme, (SAP) introduced in 1986, the country attempted to bring down fiscal deficits as part of its stabilization and adjustment programmes, often by reducing public spending on across-the-board basis, (Anyawu, et al., 1997). These reductions resulted in unprecedented economic and social costs as human resources development was neglected with adverse long-term devel-

1 http://www.africaranking.com/largest-economies-in-africa/ 
opment consequences on technical contents and know-how (Oyinlola and Adam, 2003). It therefore becomes abundantly imperative to examine the effects of these via:

(1) The productivity growth effect in Nigeria, and

(2) How government efforts have caused human capital to contribute to productivity growth in Nigeria.

\section{HYPOTHESIS}

Since the two variables of interest are human capital (Hum) and productivity growth $(t f p)$, the hypothesis test for causal relation will be stated as:

Ho: There is no causal relationship between human capital and productivity growth $H_{1}$ : There is a causal relationship between human capital and productivity growth

\section{METHODOLOGY}

The study employed a quantitative method of analysis for the study. It covered the period between 1970m and 2010. The study period selected actually covers the period before and after reforms in Nigeria; thereby given an opportunity for the assessment of productivity and human capital in Nigeria, pre and post reforms.

\subsection{Model Formulation}

A test for causality, between two variables, is basically to establish if one variable leads the other variable and/or vice-versa. In order to do this, the causality test could be adopted; which assumes that the information relevant to the prediction of the respective variables, and is contained solely in the time series data on these variables. The test involves estimating the regression of the form:

$$
\begin{aligned}
& t f p_{t}=\sum_{i=1}^{n} \alpha_{i} H u m_{t-i} \sum_{j=1}^{n} \beta_{j} t f p_{t-j}+u_{i t} . \\
& H u m_{t}=\sum_{i=1}^{n} \theta_{i} t f p_{t-i}+\sum_{j=1}^{m} \delta_{j} H u m_{t-j}+u_{2 t} .
\end{aligned}
$$

Where it is assumed that the disturbances and are uncorrelated.

Equation (1) postulates that current value of is related to past values of itself, as well as of , and equation (2) postulates a similar behavior for .

From the equations specified above, four cases of causality can be distinguished:

- Unidirectional causality from Hum to tfp is indicated if the estimated coefficients on the lagged Hum in equation (1) are statistically different from zero 
as a group (i.e., $\left.\sum \alpha_{i} \neq 0\right)$ ) and the set of estimated coefficient on the lagged tfp in equation (2) is not statistically different from zero (i.e., $\sum \delta_{j}=0$ )

- Conversely, unidirectional causality from tfp to Hum exists if the set of lagged $\mathrm{M}$ coefficients in equation (1) is not statistically different from zero in both regressions (i.e., $\sum \alpha_{i}=0$ ) and the set of the lagged tfp coefficients in equation (2) is statistically different from zero (i.e., $\sum \delta_{j} \neq 0$ ).

- Feedback, bilateral causality, is suggested when the sets of Hum and tfp coefficients are statistically different from zero in both regressions.

- Finally, independence is suggested when the sets of Hum and tfp coefficients are not statistically significant in both the regressions.

Generally, since the future cannot predict the past, if variable Hum causes variable tfp, then changes in Hum should precede changes in tfp. Therefore, in a regression of tfp on other variables (including its own past values) if we include past or lagged values of hum and it significantly improves the prediction of $t f p$, then we can say that Hum causestfp. Asimilar definition occurs if tfp granger causes Hum (Gujarati, 2009).

\subsection{Variable Measurement/ Sources}

\subsubsection{Productivity Growth}

This will be measured using the Total Factor Productivity, (tfp). Total-factor productivity (tfp) growth is a variable that accounts for effects of total output not caused by inputs (Hornstein and Krusell, 1996). If all inputs are accounted for, then, $t f p$ growth can be taken as a measure of an economy's long term technological changes or dynamism. tfp is often seen as the real driver of growth within an economy.

In an attempt to examine productivity growth in Nigeria, this study adopted the endogenous growth model as the is one of the neo-classical growth theories which adequately addresses issues on productivity growth, (Barro and Salai-Martin, 1995). Much of the recent literature distinguishes between exogenous and endogenous growth models (Barro and Salai-Martin, 1995). The important difference is that in the former the steady-state growth rate is determined exogenously, e.g., technical change while in the latter, the steady-state growth rate is determined endogenously, that is within an economy; but both models are interesting because they often leave a role for policies to be made. This determination of productivity growth was based on the neoclassical growth model as employed by Hercowitz, et al (1999) that focused on the level of productivity or the "Solow-residual". The basic building block of this study is the neoclassical production function of the representative firm in the business sector specified in equation (3) above which is assumed to be of the Cobb-Douglas capital augmented form:

$Y_{t}=A_{t} K_{t}^{\alpha} L_{t}^{1-\alpha}, \quad 0<\alpha<1$ 
Where

$Y t=$ output in period $\mathrm{t}$

$K t=$ capital stock at the beginning of period $\mathrm{t}$

$L t=$ input of labor in hours

$A t=$ total factor productivity $(t f p)$

$\mu=$ error term.

By linearizing equation (3.8) above, we take the natural log of both sides, and it becomes:

$$
\ln Y_{t}=\ln A_{t}+\alpha \ln K_{t}+(1-\alpha) \ln L_{t}+\mu_{t}
$$

tfp is affected by technical change of the neutral type, in the spirit of the neoclassical growth model. In equation (4) above, there are two unknowns, the growth rate of $t f p$ which was indexed and the parameter $\alpha$. Following the usual practice in this context, $\alpha$ is used as an estimate of the capital share, and obtain A as the residual.

But in order to generate the growth rate of tfp in a decomposed series, the error term $\mu$ can be ignored and then is made the subject, which implied;

$$
\ln A_{t}=\ln Y_{t}-\alpha \ln K_{t}-(1-\alpha) \ln L_{t}
$$

In essence, if tfp is represented by the variable $A$, then we can re-write equation (5) by introducing the difference operator, which implies:

$\Delta \ln A_{t}=\Delta \ln Y_{t}-\alpha \Delta \ln K_{t}-(1-\alpha) \Delta \ln L_{t}$

Equation (6) can be rewritten as:

$$
\Delta \operatorname{lntfp} p_{t}=\Delta \ln Y_{t}-\alpha \Delta \ln K_{t}-(1-\alpha) \Delta \ln L_{t}
$$

\subsubsection{Human Capital}

The concept of human capital refers to the stock of health, knowledge, skills, attitudes, physical and managerial effort required to manipulate capital, technology, and land among other things, to produce goods and services for human consumption (UNECA, 1990). Several variables have been used in the literature to measure the impact of education. These include public expenditure on education as a percentage of GDP (Barro and Lee, 1994), and primary, secondary, and higher school attainment. But for the purpose of this study, as shown in Table 1., gross secondary enrollment ratio will be used. This is because an average secondary entrant or high school graduate is qualified to get a technical skill, learn an art, or earn a degree. 
Table 1.: Presentation of Variable Measurement and Sources

\begin{tabular}{|l|r|r|r|}
\hline \multicolumn{1}{|c|}{ Variables } & Sources of variable & \multicolumn{1}{|c|}{$\begin{array}{c}\text { Measurement of } \\
\text { Variables }\end{array}$} & Apriori Expectation \\
\hline $\begin{array}{l}\text { TFP } \\
\text { Real GDP-IFS, 2010 } \\
\text { Labor force- IFS,2010 }\end{array}$ & Computed from & & \\
$\begin{array}{l}\text { Gross fixed capital } \\
\text { formation- IFS, 2010 }\end{array}$ & $\begin{array}{r}\text { Growth Accounting } \\
\text { method- see equation } \\
3.10\end{array}$ & Positive Growth & \\
Human Capital & $\begin{array}{r}\text { World Development } \\
\text { Indicator, 2010 }\end{array}$ & $\begin{array}{r}\text { Secondary School } \\
\text { Enrolment Rate }\end{array}$ & $\begin{array}{r}\text { Bi-Directional } \\
\text { Causality with TFP }\end{array}$ \\
\hline
\end{tabular}

Source: Authors'

\section{Estimation Technique}

Objective 1: To measure productivity growth through TFP, the equation (5) will be applied. Total Factor Productivity is the ratio of total output to the collection of labor and capital as factors of production. The choice of this variable in measuring total productivity is made because it reflects the effects of technology on output production, since TFP is a change in output that does not depend on labor and capital (Mohammad and Jalil, 2011). Since the concept of productivity which can be used to measure performance can also be used to assess how well an economy has performed in terms of resource utilization.

Objective 2: In order to establish if any causal relationship exist between productivity growth (tfp) and human capital (Hum) in Nigeria, the Granger causality test will be adopted ${ }^{2}$. Taking a clue from equation (1) and (2), the Granger approach will be achieved by using Engle-Granger method of estimating the causality (adapted from Gujarati and Porter, 2009).

\section{ANALYSIS AND DISCUSSION OF RESULTS}

\subsection{Derivation of the Total Factor Productivity (TFP) in Nigeria}

Basically, we used the simple growth-accounting exercise to estimate the growth rate of the TFP (the Solow residuals) assuming a constant labor share ratio of 0.6 while 0.4 is assumed as a constant capital share ratio. (Akinlo, 2003). The adoption of 0.6 is in view of the fact that in most developing economies, the production process is more of a labor intensive mechanism when compared to capital intensive methods of production. Thus, for the purpose of trend analysis, TFP growth was calculated using the specification in equation (5). The output $(\mathrm{Y})$ of the economy rep-

2. Multivariate Granger causality analysis is usually performed by fitting a vector autoregressive model (VAR) to the time series. However, in the case of a two-variable case $\mathrm{d}\{\backslash$ displaystyle as stated within this study, the simple Granger causality test will be suitable for our analysis (Gujarati, 2009) 
resented the growth rate of real GDP which was proxied with the RGDP; while the capital (K) represents the growth rate of capital which was proxied with a stock variable- gross fixed capital formation for the Nigerian economy. The variable labor (L) represents the growth rate of labor and was proxied with the data of the labor force of the Nigerian economy.

The growth rate of TFP generated revealed the following pattern:

Figure 3.: The Pattern of Productivity growth (TFP) in Nigeria, 1970-2010

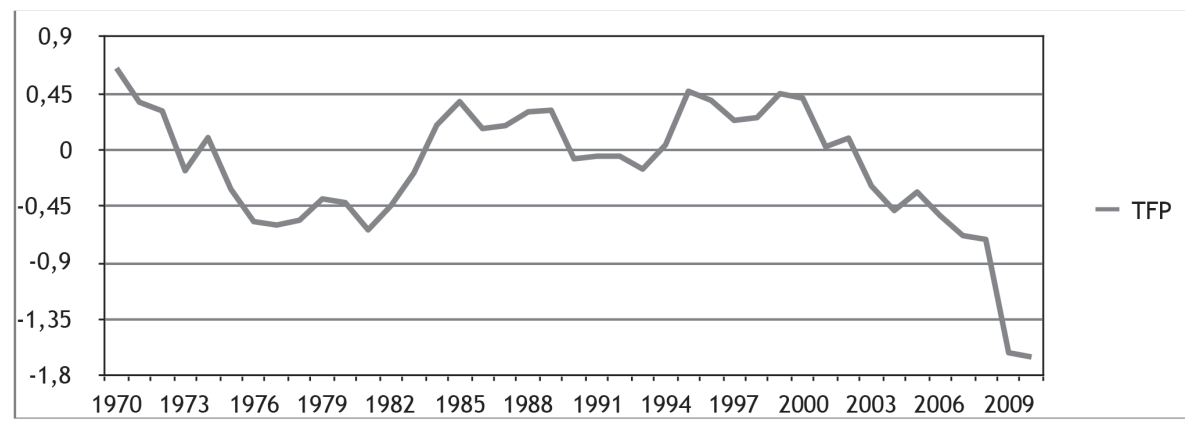

Source: Author's computation

The implication of growth pattern in Figure 3. above revealed that the productivity growth in Nigeria has been unstable as it oscillated between $0.6 \% \mathrm{df}$ in 1970 to $-0.4 \%$ in 1980 and declined further to $-0.06 \%$ in 1990 and further to $0.4 \%$ in year 2000. This pattern is consistent with some of the earlier studies on TFP (Louis and Adenikinju, 2002; Olaoye, 1985 and Adesina, 2011). It is worthy of note that despite the declining pattern observed in the growth rate of TFP, there were some periods TFP attempted to take a major leap from the observed declining and unstable trend which had some major implications for the pattern of productivity in Nigeria. For instance, in 1970, TFP was about $0.6 \%$, while in mid-1980s, TFP was about $0.31 \%$ and in the mid-1990s, TFP was about $0.5 \%$. This pattern is similar to the result generated by Alwyn (1995), when he studied the TFP growth in Asia to be ०\%, and the manufacturing sector growth was $1 \%$, while the overall TFP growth rate in China and Hong Kong was 2.3\%. The same was reported for the Singapore economy where TFP growth was low due to inadequate skills to meet current challenges; but a rebound was recorded between the mid-1990s and early 2000, which was greatly attributed to human capital development, and capital accumulation.

Before the year 2000, Nigeria although was referred to as a traditional economy, this was because a look at the GDP revealed that the agricultural sector was contributing more to GDP than any other sector such as the manufacturing sector. For instance, as at 1970, agriculture contributed $48.8 \%$ and by 1980 , it stood at $25 \%$; while in 1990 , it contributed about 3०\% to total GDP, and by year 2000, agriculture contributed $32 \%$ to total GDP; this is against the pattern of the manufacturing industry which grew slowly 
over the years ; for instance, in 1970, the manufacturing sector contributed about $4.8 \%$ to GDP while in 1981, the manufacturing industry contributed about 8\% to GDP, while in 1990 , it contributed about $8 \%$ to GDP, and by year 2000 , it was about $6 \%$ of the total GDP (CBN Statistical Bulletin, 2002). The slowdown in the rate of contributions of the agricultural sector and manufacturing sector between 1970 and 1980 could have been as a result of the de-industrialization experienced in the Nigerian economy during the period. The de-industrialization could be attributed to the revenue generated from natural resource sales such as oil earnings, which in turn caused little incentive for institutionbuilding and failed to implement growth enhancing reforms. Higher corruption, more rent-seeking activity, greater civil conflict, and erosion of social capital are some of the outcomes associated with the Nigerian deindustrialization experience. This is as which led to the adoption of the SAP in 1986. The Structural Adjustment Programme (SAP) of 1986, which had as one of its objective, boosting production through industrialization could have accounted for the revival of productive capacity in Nigeria in the mid-1980s.

Furthermore, it is not impossible for the observed pattern of major sectors in the economy to explain the declining drive of TFP within the Nigerian economy given that the agricultural sector employs more of the labor force than any other sector. Generally, it was observed that between 1981 and 1990, the contributions of the agricultural sector to GDP grew by just $5 \%$, while between 1990 and year 2000, the difference in the contribution of the agricultural sector to overall output increase by just $2 \%$ (Ayodele and Falokun, 2003). This is because despite the fact that the agricultural sector takes a larger chunk of the total goods and services produced within the economy, the productive capacity may still be very low as evident in the kind of rudimentary techniques used for farming. The manufacturing sector is even more worrisome as its contribution to GDP revealed a declining trend over the years. This may be due to the fact that the manufacturing sector makes productive techniques that are not in consonance with best practices. Besides, it may be that there are low skilled personnel to drive creativity, innovation and invention; thus, resulting in low productivity. In addition, the manufacturing sector is seen to produce more of light household's consumables and less of capital goods, thereby accounting for low productivity.

\subsection{Test of Causality between Human Capital and Productivity Growth}

To provide empirical evidence on the fundamental question of whether human capital development causes productivity growth or whether productivity growth enhances human capital development, the granger causality test (GCT) is a tool for ascertaining this causal relationship. In Table 2., the GCT test carried out revealed that short-running-directional causality existed between TFP and human capital at $5 \%$ level of significance; but there was no relationship between human capital and TFP at $5 \%$ level of significance; therefore, the null hypothesis will be rejected in the first case, while the null hypothesis will be accepted in the second case. 
Table 2.: Pairwise Granger Causality Tests

\begin{tabular}{|l|r|r|r|}
\hline \multicolumn{5}{|c|}{ Sample: 1970-2010 } \\
\hline Lags: 2 & Obs & F-Statistic & Prob. \\
\hline Null Hypothesis: & 39 & & \\
\hline $\begin{array}{l}\text { TFP does not Granger } \\
\text { Cause HUM } \\
\begin{array}{l}\text { HUM does not Granger } \\
\text { Cause TFP }\end{array}\end{array}$ & & 4.18770 & 0.0239 \\
\hline
\end{tabular}

Source: Authors'

The estimate from the Granger causality estimate revealed a unidirectional causality between human Capital and productivity growth in Nigeria. The unidirectional causality between TFP and human capital at $5 \%$ level of significance implies that TFP growth is seen to cause human capital development. But human capital development has not caused TFP growth. Therefore, we reject the null hypothesis at $5 \%$ for the second case. The uni- directional causality implied that productivity growth has facilitated the advancement of human stock of knowledge; but human capital has not caused productivity growth in Nigeria.It is interesting to know that productivity growth (which basically involves technological know-how and processes) has facilitated human activities. This is evident in teaching methods via the use of Information and Communication Technologies (ICT), as well as improvement in other sectors such as mechanized activities in farming, manufacturing, transportation, and communication has facilitated human development.

But, a look at the trend relationship between TFP and human capital will give an insight to the causality test in Table 2.

Figure 4.: Growth Rate of TFP and Human Capital

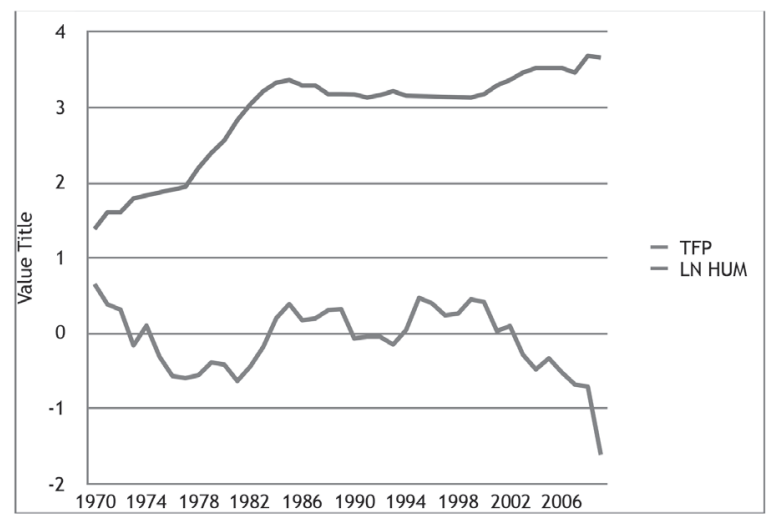

Source: TFP: Authors' computation

Human Capital: (Secondary school enrollment ratio), World Development Indicators, 2011 
Figure 4. revealed that the trend relationship between human capital and TFP growth had human capital growing was faster and higher than productivity growth. Human capital which was initially low at 4 percent in 1970 while TFP was about $0.6 \%$; by 1980 , TFP stood at $-0.4 \%$ while human capital grew at $13 \%$ in 1980 ; a fall in the level of human capital was experienced in the early 1990s to an average of 23 percent but TFP declined to $-0.06 \%$; but by mid 1990 s it started growing steadily from 20 percent to about 35 percent by 2005 while TFP was also positive at an average of $0.4 \%$. However, the TFP and human capital level can be seen to be growing steadily in the mid-1970s, but while the level of human capital grew over the years, TFP experienced a declining growth. From this trend, it can be deduced that initially, the productive level of the economy was higher than human capital, but by the late 1970s, human capital grew faster than TFP. This may be as a result of the fact that while the acquisition of skill by the populace grew over the years in terms of knowledge and technical know-how, the areas for dissipating these skills were not really evident. This is evident in the trend of unemployment situation in Nigeria; as it grew from $2.4 \%$ in 1970 to $6.3 \%$ in 1980 and then by year 2000 it was about $13 \%$ (International Financial Statistics, 2011). The fascinating trend between unemployment and human capital development is that a similar pattern is generated for both variables, thereby having severe implications for productivity growth. This explains why human capital has not caused productivity growth, because, the trend revealed a positive relationship between human capital and unemployment rate; that is the higher the human capital developed, the higher the rate of unemployment

Figure 5.: Relationship between Human Capital and Unemployment in Nigeria

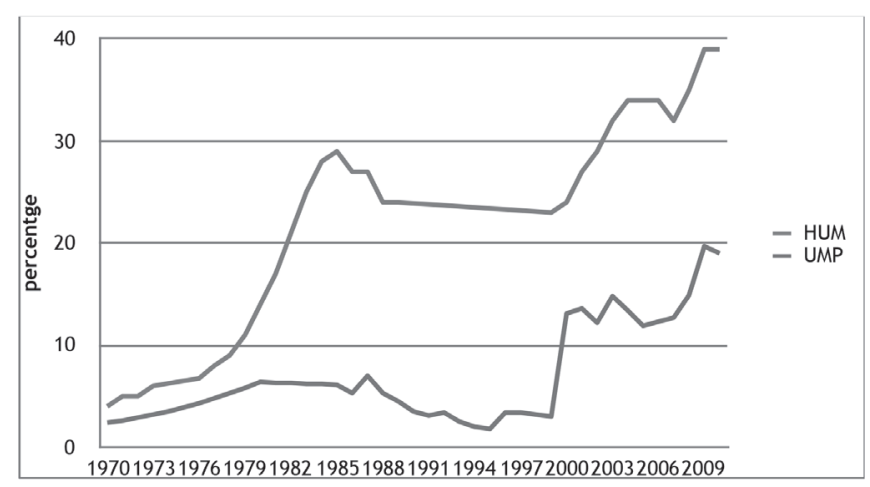

Source: Unemployment Rate: International Financial Statistics, 2011

Human Capital: (Secondary school enrollment ratio), World Development Indicators, 2011

In effect, since productivity patterns reveal the level and efficiency of real activities within any economy, it therefore implied that the aim of the Nigerian government towards encouraging self-sufficiency, creating jobs and boosting overall productivity remains in doubt. Since, to a large extent, some of these goals cannot be 
said to have been realized because there is still high unemployment, heavy reliance on trading and importation of food items and raw materials to augment local production (Ayodele and Falokun, 2003). In addition, there are scanty number of large scale commercial cultivators using modern techniques of farming and a large number of peasant farmers relying basically on traditional farming techniques. In essence, at the national level, low productivity growth reduces living standards because less real income decreases people's ability to purchase goods and services, enjoy leisure, improve housing and education and contribute to social and environmental programs.

\section{CONTRIBUTION TO KNOWLEDGE}

The study has been able to lend support to previous studies that productivity growth will promote human capital development. However, it also depicts that no matter how little advancement in technical know-how may be via productivity, human capital will usually benefit positively. However, the study revealed that for human capital to affect productivity, human capital development may need to be appropriately structured, annexed and channeled for productivity purposes, if not, general human capital development may just result in general economic impact instead of real, specific and directed productive impacts.

Figure 6.: The Vicious Circle of Poverty

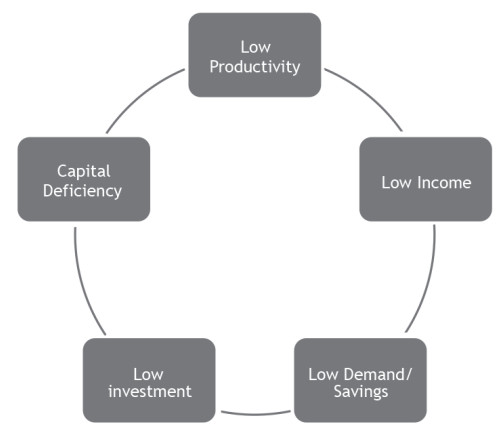

Source: authors' adjustment from Jhingan, 2012

In economic thought, scholars such as Ragner Nurske have observed a vicious circle that could cause poverty and lower productivity growth, which is commonly referred to as the vicious circles of poverty- this is a circular constellation of forces acting and reacting upon one another in such a way as to keep a poor country in a state of poverty, (Jhingan, 2012). Figure 6., in its original conception, the vicious cycle of poverty in Figure 6. adduces that physical capital deficiency results in low productivity growth. However, since physical capital is itself is man-made, it could be reasoned that human capital development is a sine qua non to development and improvement in physical capital. A general explanation of productivity growth should therefore 
include capital accumulation for investment purposes. However, this investment should include both human and physical capital by private firm owners and the government. For particular industries, on-the-job-training paves way for greater productivity, while general training leads to economy-wide skill acquisitions by workers for productivity. The import of investment in human capital is summed up in Alfred Marshall's submission that was noted by Becker (1994) "the most valuable of all capital is that invested in human beings"

If the population constitutes people with low technical knowledge, low entrepreneurial drive, semi-skilled workers, unskilled laborers, or even illiterates, natural resources will remain mis-utilised or underutilized. Therefore, the next best interest should be what should be the way out to tackling some of these issues mitigating productivity growth and human capital development?

\section{RECOMMENDATION AND CONCLUSION}

In view of the results generated, it becomes pertinent to advance certain issues that could enhance productivity growth in Nigeria, given the dynamic human capacity endowment Nigeria possesses. Hence, these proposals are discussed in turns:

(3) Harmonious Circle of Wealth: In economic thought, it is expected that if there is high income, as reflected in the national income of Nigeria, (CBN report, 2010), a relative even distribution of such income will lead to increased savings on the supply side of the market, as well high demand on the demand side of the market. This will encourage investors to invest more, which may be due to increased savings or increased demand, which in turn will lead to efficient use of capital, as well as accumulation, and an eventually high productivity results.

Figure 7.: The Virtuous Circle of Poverty

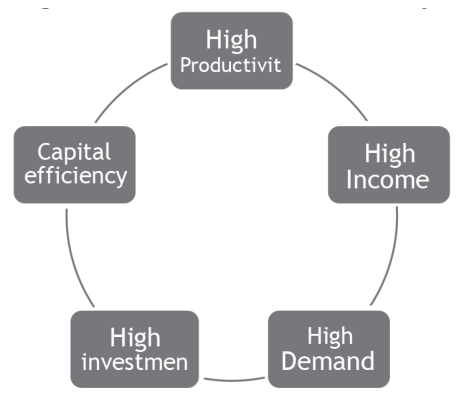

Source: authors' adjustment

With regard to the findings of this study, taking a clue from the economy of Singapore, Alwyn (1995) discovered that capital accumulation was the main source of growth in Singapore, while Soon and Soon (1997) discovered that 
a total rebound in TFP in Singapore was due to human capital development, thus, validating the propositions of RagnerNurkse. A consideration of these factors in the light of the realities which operates in Nigeria, can guide policy formulation and implementation; where human capital development that will adopt, acquire and diffuse foreign technologies will be relaxed as well as encourage the development of globally competitive indigenous technologies.

(4) Process-based Training: A number of educators may disagree with the idea of practices as "process-based" because components of products (in writing) or components of lesson instruction (in the form of mini-lessons or follow-up class discussions) oftentimes occur. But the logic is like this: teaching practices should have a balance of relevant and nascent practical sessions with theories, especially in the Science and technology based discipline where students are expected to spend time by learning through doing; it also includes other non-science discipline which are relevant to human existence and sustenance. This is because leaning by doing can lead to problem solving, discovery of new ideas, designing a product, as well as leading to productdevelopment which is not commonly part of math problem-solving lessons. A rigorous mind that is well developed through process teaching methods will be creative and innovative in his thinking and activities thus, having direct implications for productivity enhancements in any economy. While advocating for process based learning, it is important to ensure that the dynamics of time be taken into consideration, as it is commonly observed that change is a continuous process. Therefore, the methods of doing things two decades ago may be significantly different today; as a result, one must inculcate dynamic learning process in teaching methods. For instance, in recent times, the use of ICTs in teaching is become a nascent order, as a result, it is pertinent that such methods be inculcated in skill acquisition and teaching methods. In addition, the gap between industries and educational institutions should be bridged, such that industries can institutions have a feed-back mechanism of what is required of graduates to make them relevant and competitive, as well as what industries require to become more productive, given research outputs. Beyond the process-based training, the issue of technical education should not be side-tracked, or less reckoned with. This is because some talents may have the ability to understand theoretical contents and subsequently apply to practical issues, but in some other instances, there may be some who understand just the practical application of some technical details and are not willing to go through the theoretical details. Germane instances are the auto-mechanics in Nigeria, where most of these mechanics get certified through learning by doing, as a result they engage in trial and error practices which are capable of reducing productivity. Hence, there may be the need to scale-up existing abilities to meet with current challenges in different industries; in addition, technical education and informal learning process should be scaled-up to ensure 
effective delivery. This could be achieved by bridging the gap between technical in the agricultural sector, which remains the largest employer of labor in Nigeria, it is equally encouraged that peasant practices be done away with, while mechanized and improved processes be adopted; this will boost output and enhance productivity growth.

(5) Entrepreneurship Education: Employment is the life line of any economy. "Human development will definitely be grossly undermined and impaired without employment". How soon Nigeria sets to address the problems of mass. To tackle the challenge of unemployment in Nigeria depends on how speedily it is able to develop the millions of its labor force into a knowledgeable and skilled people needed for the required change (NEEDS document, 2004). The need for self-employment is a critical issue in recent times considering the fact that the search for job keeps increasing. The Entrepreneurship Development Programme, as an urgent mechanism to youth unemployment was specifically designed for the Nigerian youths, informing them about the world of business and opportunities to create their own businesses. The EDP provides youths with insights into entrepreneurship and enterprise; it aims to help them realistically consider the options of starting a small business or of selfemployment. The reason why the EDP was set up was to create employment opportunities for self-employed youths as well as the other young people they employ. Besides, the programme was designed to bring alienated and marginalized youths back into the economic mainstream and giving them a sense of meaning and belonging as well as to help in addressing some of the socio-psychological problems and delinquency that arise from joblessness. In addition, to help youths develop new skills and experiences that can then be applied to other challenges in life; promote innovation and resilience in youths; promote the revitalization of the local communities by providing valuable goods and services; capitalize on the fact that young entrepreneurs may be particularly responsive to new economic opportunities and trends.

(6) Good Governance: Good governance is believed to be able to contribute significantly to the development of human capital in Nigeria. For instance, the capacity of individuals and businesses to exploit the potential of the Nigerian economy will be enhanced where the scourge of corruption and bad governance are reduced to the barest minimum. Besides, policies that will promote a social charter, where contract between individuals and government will be enhanced should be ensured. Particularly, government will recognize the rights and responsibilities of individuals such as education, health, housing and security and make adequate budgetary allocations. This should be done in view of the rich endowment of natural and human resources present in Nigeria; because for decades, the Nigerian socioeconomic conditions have declined despite increasing revenue from crude oil (NEEDS, 2004). In essence boosting 
productivity growth and empowering people calls for a human rights approach to development planning where policies designed and implemented places people at the center of development efforts. Aside this, the government should promote public-private partnership by developing programmes that will boost productivity patterns through ability to develop and manage new technologies, mount schemes that will discourage brain drain and discourage migration, as well as channeling corporate and social responsibilities to channels where productivity can be enhanced. It is noteworthy the entrepreneurs, investors and businessmen, though are attracted by the Nigerian market, some other issues that may discourage investment as well as impede productivity which must be addressed adequately include, corrupt practices, bribery, infrastructural decay, electricity, cultural rigidities, as well as security challenges.

(7) Monitoring and Evaluation: For any economy to advance in all spheres, it is very important that whatever policies are being implemented, adequate monitoring process through relevant bodies are put in place. This is important feedback mechanism for evaluation process, as to where the economy was, where it is and where it intends to be. If set expectations are met, there will be a multiplier improvement in the economy, but if not, a proper documentation will help review policies as required. In essence, domestic factors, the variation in the level of education embodied in the labor force is one of the primary reasons for the observed differences in productivity among countries. For Sub-Saharan countries and particularly Nigeria, it has been observed that the relevant bottleneck preventing the adoption and development of new technology is the lack of human capital necessary to implement the new technology in a productive fashion; this therefore, may account for the human capital not causing productivity growth in Nigeria. 


\section{REFERENCES}

Adesina, Growing Nigeria's Agriculture. Document: Library International Institute for Tropic Agriculture, Ibadan Nigeria, 2011.

Ahmed M. Q. and Bukhari H. K. S., Determinants of Total Factor Productivity in Pakistan. Working Papers/Research Report 68, 2007 .

Akinlo, A. E. Impact of Macroeconomic Factors on Total Factor Productivity in Sub-Saharan African Countries. Research Paper No. 2005/39 (2005). UN-WIDER.

Akinlo, A. E., Macroeconomic Factors and Total Factor Productivity in Sub-Saharan Africa Countries. International Research Journal of Finance and Economics. Euro Journals Publishing, Inc. 2006: 1-18

Alwyn, Y., The Tyranny of Numbers: Confronting the Statistical Realities of the East Asian Experience. The Quarterly Journal of Economics, (1995): 641-680

Anyawu J. C., Oyefusi A., Oaikhenan H. and F.A. Dimowo 1997. The Structure of the Nigerian Economy. Joanee Educational Publishers LTD

Ayodele A. S. and Falokun G. O., The Nigerian Economy and Pattern of Development. Printoteque, 32, Shipeolu Street, Palmgroove, Lagos, 2003.

Barro, R. and Jong - Wa L., International Comparisons of the Educational Attainment. Journal of Monetary Economics, (1991): 363 -394

Barro, Robert J. "Sala-i Martin X (2004) Economic Growth." Aufl. Massachusetts Institute of Technology (MIT), 2004.

Becker, Gary S. "Human capital revisited." In Human Capital: A Theoretical and Empirical Analysis with Special Reference to Education (3rd Edition), The University of Chicago Press, 1994: 15-28

Budget Report, 2014. Budget Office of the Federation, Federal Republic of Nigeria.

Central Bank of Nigeria, 2005. Statistical Bulletin. CBN, Abuja.

Chete, Louis N., and Adeola F. Adenikinju. Productivity growth in Nigerian manufacturing and its correlation to trade policy regimes/indexes (1962-1985). No. RP_126. 2002.

Danquah M., Enrique Moral-B. and Quattara B. Total Factor Productivity Growth and its Determinants Nonparametric and Model Averaging. Working Paper, 2011.

Dauda R. O. S., The Role of Human Capital in Economic Development-An Empirical Study of the Nigerian Case. Oxford Business \& Economics Conference Program, 2010.

Estevao M. and T. Severo, Financial Shocks and Total Factor Productivity Growth. International Monetary Fund. Working Paper.; Western Hemisphere Department WP/10/23, 2010.

Gujarati D. N. and D. C. Porter, Basic Econometrics. McGraw-Hill/ Irwin Companies Inc., 2009.

Gusau B. U., Educational Reforms in Nigeria: Successive Years of Inconsistencies and Confusions. Gusau Educational Development Association (Geda), Interactive Session. January, 2008.

Hercowitz Z., Yaacov L. and R. Melnick, The Impact of Macroeconomic Factors on Productivity in Israel, 1960-1966. Bank of Israel Economic Review 72, 1999.

Idris J., Determinants of Total Factor Productivity Growth in Malaysia. Journal of Economic Cooperation, $28,3(2007): 41-5^{8}$ 
Iwayemi, A. and Ayodele, A. S., Economic Adjustment and the Public Utility Sector. In Macroeconomic Policy Issues in an Open Economy. A Case Study of Nigeria. NCEMA, Ibadan Nigeria, 1995.

Jorgenson D. W. and Grilliches Z., The Explanation of Productivity Change. Review of Economic Studies, $34,(1967): 349-383$

Jhingan M. L., The Economics of Development and Planning. Vrinda Publications Ltd, Delhi, 2012.

Limskul K., Economic Development and Structural Change in Thailand. Ph. D Thesis, Faculty of Economics, Nagoya University, Japan, 1988.

Meier, G.M., Leading Issues in Economic Development. 2nd Ed. Oxford: Oxford University Press, 1970.

Miller, S.M. and Upadhyay, M.P., The Effects of Openness, Trade Orientation, and Human Capital on

Total Factor Productivity. Journal of Development Economics 63, (2000): 399-423

Mincer, Jacob, Investment in Human Capital and Personal Income Distribution. Edward Elgar

Publishing, 1993.

Mohammad A. D. T. and Jalil T. An Empirical Analysis of Total Factor Productivity in the Economy of Iran. 2011 International Conference on Economics and Finance Research IPEDR vol.4. (2011) Š IACSIT Press, Singapore

Nadiri, M.I., Some Approaches to the Theory and Measurement of Total Factor Productivity: A Survey. Journal of Economic Literature, 8, no.2 (1970): 194-254

Ogunleye E.O. and Ayeni R.K., The Link Between Export and Total Factor Productivity: Evidence from Nigeria. International Research Journal of Finance and Economics; EuroJournals Publishing Inc. 2008.

Oyinlola, O.O. and Adam, J.A., Public Expenditure and Human Development in Nigeria, in Human Resource Development in Africa. Selected Papers for 2002 NES Annual Conference, Nigerian Economic Society, Ibadan, (2003): $5^{3-7^{8}}$

Ousmanou N., Joachim N. B. and S. Tachi, Understanding Total Factor Productivity Growth in SubSaharan Africa Countries. Working paper series Secetariat for Institutional Support for Economic in Africa (SISERA) 2006/3.

Park J., Projectivity of Long-Term Total Factor Productivity Growth for 12 Asian Economies. ADB Economics Working Paper Series, No. 227., 2010.

Sebastian E., Openness, Productivity and Growth: What do we really Know. NBER Working Paper Series 5978, NBER, 1050 Massachusets Avenue Cambridge, MA o2138, March 1997.

Soon T. W. and Benson S. S. S., Total Factor Productivity Growth in Singapore: Methodology and Trends. Capital Stock Conference March 1997Agenda Item VII, 1997.

Solow, R., A Contribution to the Theory of Economic Growth. Quarterly Journal of Economics Vol. 7०, No. 1 Feb, 1956: 65-94

Tinakorn, P. and Sussangkarn, C., Research and International Development for Macroeconomic Policy Formulation. Bangkok: National Economic and Social Development Board and Thailand Development Research Institution, 1994.

Tinakorn, P. and Sussangkarn, C., Total Factor Productivity in Thailand, 1980-1995. Bangkok National Economic and Social Development Board and Thailand Development Research Institution, 1998.

Todaro M. P. and Smith S. C., Economic Development. Pearson Education Limited, Eleventh edition, 2011. 
United Nations Economic Commission for Africa, Handbook of Manpower Planning in Africa. Addis Ababa. UNECA, 1990.

UNIDO, Benchmarking Industrial Performance. Industrial Development Report, (2002/2003), 2003. 